\title{
A Quantitative Evaluation of the Potential Effects of Trade Policy Reversal in Sri Lanka: A Computable General Equilibrium (CGE) Analysis
}

\author{
Tilak Susantha Liyanaarachchi ${ }^{+1}$, Jayatilleke S. Bandara ${ }^{2}$ and \\ Athula Naranpanawa ${ }^{3}$
}

\begin{abstract}
In recent years there has been a trend in rising protectionism and a reversal of trade policy reforms in some developed and developing countries, particularly after the global financial crisis. Although some researchers and practitioners have discussed recent trends in trade policy reversal in both developed and developing countries in recent years, no serious attempts have been made to examine the effects of trade policy reversal in a developing country within an economy-wide framework. The current paper attempts to fill this research gap by answering the question: Can developing countries benefit from trade policy reversals? The study focuses particularly on the case of Sri Lanka. To address this central research aim the paper first reviews recent trends in import duty and para-tariffs in Sri Lanka, particularly after the global financial crisis. An economy-wide computable general equilibrium (CGE) model was then used to evaluate the effects of trade policy reversal on the Sri Lankan economy. The results of the Sri Lankan case study presented suggest that developing countries will not benefit from trade policy reversal at either the macro level or industry level.
\end{abstract}

\section{Introduction}

The role of trade liberalisation in economic growth and poverty alleviation has been a consistent focus of policy makers and practitioners in developing countries. As such there is a large body of literature on the link between trade and growth (see Singh, 2010 for an excellent survey), as well as the link between trade poverty (see for example Bandara, 2011 and Winters et al., 2004). In reviewing this empirical literature it is clear there is strong evidence to support the positive link between trade and poverty through high level of growth resulting from trade policy reforms in developing countries. However, the re-emergence of protectionism and trade policy reversal in some

${ }^{1} \mathrm{PhD}$ candidate, ${ }^{2}$ Associate Professor and ${ }^{3}$ Lecturer Department of Accounting, Finance and Economics, Griffith Business School, Griffith University, Queensland 4111, Australia.

† Corresponding author, email: t.liyanaarachchi@griffith.edu.au 
developed and developing countries in recent years has been a main concern of policy analysts and trade policy practitioners. Bussière et al. (2011) found evidence from opinion surveys to show that since the early years of the twenty first century, there has been an increasing pressure from the public for more economic protection. Furthermore, it is possible that this has intensified since the start of the financial crisis. Despite G20 leaders having pledged in 2008 to avoid protectionist measures, Gamberoni and Newfarmer (2009) found evidence that several countries, including 17 of those within the G20, have implemented 47 measures to restrict trade at the expense of other countries. As a response to this new trend, economists have expressed their concerns by indicating that raising trade barriers not only has a negative impact on growth but also creates an environment necessary for a prolonged economic contraction at the global level. It is therefore interesting to note that despite the availability of clear evidence on rising protectionism and trade policy reversal in some countries in recent years, no serious attempts have made to examine the economy-wide effects of these new trends in a systematic way, in particular focusing on developing countries.

Sri Lanka provides an ideal case study to investigate the above issue in comprehensive manner for a number of reasons. Firstly, Sri Lanka was the first country to open the economy in South Asia in 1977 and continued with open economic policies even throughout the nearly three decades of long brutal war. Secondly, Sri Lanka managed to maintain a satisfactory economic growth and reduce poverty by implementing trade policy reforms during the war between 1983 and 2009. Thirdly, it is currently attempting to accelerate its post-war economic growth and to achieve long run peace and stability. Finally, a new protectionist trend has emerged in recent years in the country. Similar to other countries in that it takes the form of para-tariffs while the custom duties remain without much change (Kaminski and $\mathrm{Ng}, 2013$ ), this tendency has become more prominent in the Sri Lankan economy over the last decade. This new trend has also come to be known as the "trade policy reversal" in recent trade policy discussions (Pursell and Ahsan, 2011; Athukorala, 2012).

The Sri Lankan economy, which has been responding to the continuation of liberalisation policies throughout the last three decades, now has to face policy confusion due to recent trends in trade policy reversal. The export based manufacturing sector, which heavily depends on imported raw materials and intermediate goods, will face an increase in cost of production. Since foreign goods are now more expensive in the domestic market, the investors who allocate limited resources to produce import substitutes will bring inefficiencies and harmful effects to the economy in the long term. The impact resulting from an increase in trade restrictions may also bring unfavourable outcomes for certain groups of households while having a 
positive impact on others. From past experience, Sri Lanka was able to reduce considerable amount of poverty through employment creation due to expansion of the manufacturing sector as a result of trade liberalisation (see Bandara and Naranpanawa, 2014). It did, however, take a number of decades to achieve these positive outcomes in the economy.

Against the above background, this study aims to answer the question: Can returning to protectionism benefit developing countries? To address this question, a detailed Sri Lankan case study will be used involving the development of an economy-wide computable general equilibrium (CGE) model. The rest of the paper is structured as follows: section 2 provides an overview of trade policy changes in the Sri Lankan economy, section 3 provides the recent trends in the trade sector, section 4 presents the methodology of the paper, section 5 presents the empirical results and section 6 will conclude the paper.

\section{Trade Policy Regime and the Sri Lankan Economy: A Brief Overview}

The post-independent economic structure has been greatly influenced by developments during the British colonial period (Snodgrass, 1966). The economic structure that independent Sri Lankan inherited from the colonial past was an excellent example for a "dualistic export economy" in which a modern plantation sector including tea, rubber and coconut which used relatively abundant land, cheap South Indian hired labour and foreign entrepreneurship, flourished alongside the traditional subsistence agricultural sector. Although Sri Lanka continued with its colonial open economic policies immediately after gaining independence in 1948, it implemented importsubstituting protectionist trade and industrial policies as a response to the balance of payment crisis faced by the country in the late 1950s. As a result the Sri Lankan economy remained as one of the most restrictive economies from the late 1950s until 1977.

During this period, international trade was controlled by the protectionist import-substitution trade policy with a range of import and exchange restrictions (Athukorala and Rajapatirana, 2000). During the closed economic regime, Sri Lanka faced an insurmountable number of economic setbacks (Dunham and Kelegama, 1994). While inflation, unemployment and poverty were rising, the external sector was facing severe pressure due to a widening trade deficit which emerged mid-1970s. The situation continued to be worsened immediately after the first oil shock in 1973 with the subsequent policy response involving an increase on import controls. The unsustainability which arose from these inward-looking protectionist trade 
and industrialisation policies brought into power, during 1977, a pro-western, market-oriented right-of-centre government.

This new government implemented a far-reaching open economic policy package, as was pledged during the general election campaign in 1977, and by doing so, Sri Lanka became the first South Asian country to open its economy to the rest of the world. The details of this policy package have extensively been documented (Cuthbertson and Athukorala, 1990; Athukorala and Jayasuriya, 1994; Dunham, 1997; Athukorala and Rajapatirana, 2000). The 1977 economic reform package included the removal of most quantitative restrictions on imports and a replacement of these with tariffs, a removal of many exchange controls and the floating of the exchange rate, and an introduction of measurement to attract foreign direct investment.

This process of opening up of the economy brought upon it several structural changes (Jayawardena et al., 1987; Kelegama and Dunham, 1994). First, the importance of the agricultural sector in the economy was replaced by manufacturing and services sectors. The export sector also successfully diversified from primary agricultural to labour intensive manufacturing exports and the economy experienced higher economic growth. The export oriented and labour intensive ready-made garment industry became the main export earning sector by the 1990s (Bandara and Naranpanawa, 2014) and was closely followed by an increase in the country's level of employment. This was especially the case in the manufacturing sector where low skilled workers benefitted immensely from the expansion of labour intensive exporting industries (Wignaraja, 1998; Kelegama and Foley, 1999). However, despite the positive outcomes at the beginning of the trade liberalisation, Sri Lanka did not experience further diversification in the manufacturing sector. This lack of progress in trade liberalisation in the latter part partially explains why Sri Lanka did not perform in terms of growth in trade, competitiveness and further diversification in the manufacturing export sector.

Over the last 65 years in Sri Lanka, the poverty level has declined while the income inequality has been growing. The only exception to this was a slight decline in income equality during 2006/2007 (Naranpanawa, 2005). According to the most recent Household Income and Expenditure Survey (HIES) in 2010, poverty head count index was $8.9 \%$ which is a decline from $26 \%$ in 1991 (see Figure 1). Between 1991 and 2010 national poverty increased by $3 \%$ from 1990/91 to $1995 / 96$ followed by a decline of $6 \%$ from $1995 / 96$ to 2002 . It declined a further $7.5 \%$ between 2002 and 2006/07 and another $6.3 \%$ from $2006 / 07$ to $2009 / 10$. However, disaggregated poverty head count index for various years discloses that most of the regions do not show a convergence patterns in poverty reduction. In 2006/07, rural poverty incidence was more than two times higher than urban poverty which was 
recorded as $6.7 \%$. This shows uneven distribution of poverty across the country.

Figure 1: Distribution of poverty at national, urban, rural and estate levels

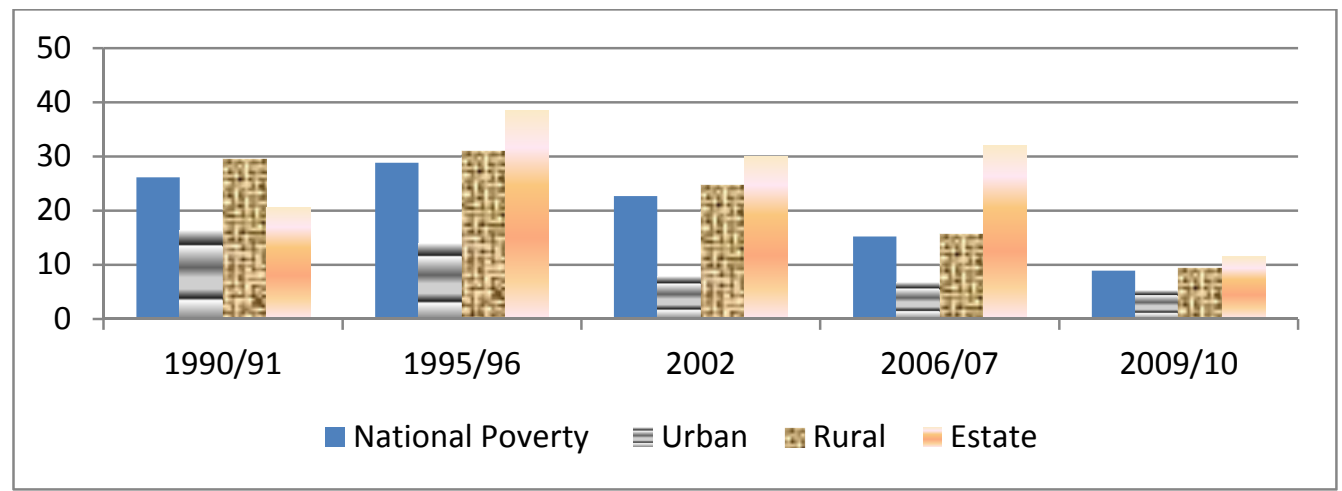

Source: Department of Census and Statistics (2004, 2006 and 2010), Sri Lanka

\section{Recent Trends in the Trade Sector}

Although successive governments which have come to power in Sri Lanka since 1977 have been committed to the continuation of open economic policies as a broad policy (including during the separatist war), there has been an emerging trend in reversal in trade policies in recent years. It is also evident that trends in Sri Lankan export income, as a percentage of GDP, have recorded a continuous decline during the last twelve years (see Figure 2).

Figure 2: $\quad$ Trade performances \& political regimes with trade policies changes

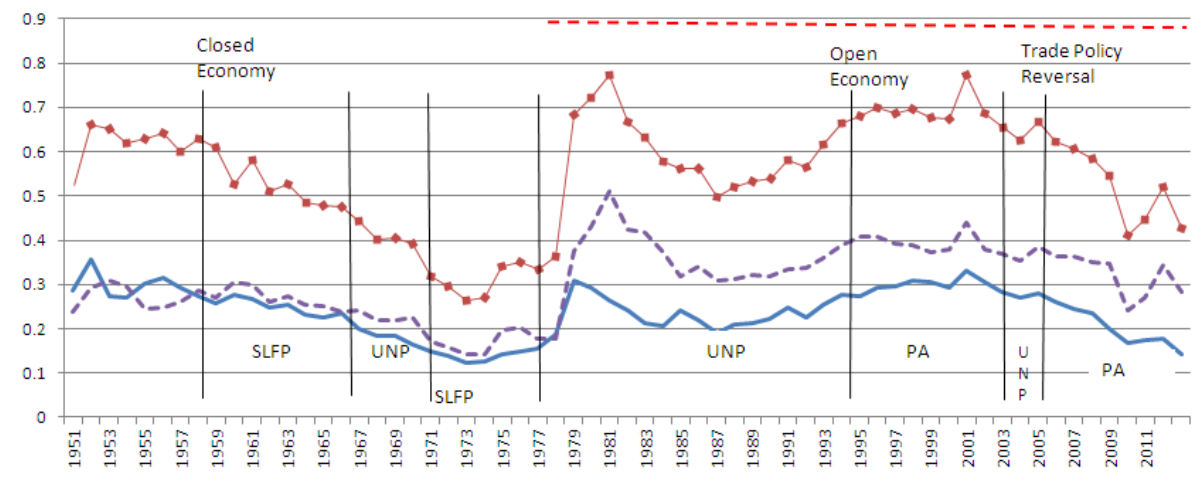

$\longrightarrow$ trade openess Export(\% of GDP) - - Imports $(\%$ of GDP) Year 
Recent trends in export, imports and trade openness show a significant trade policy reversal in Sri Lanka (Athukorala, 2012). As shown in Figure 2, openness to international trade, as measured by trade integration ratio (trade/GDP), has gradually declined since 2000 with a sharp drop between 2008 and 2009 (Central Bank, 2012). Despite a continuous decline in international trade, import duties as a percentage of government revenue have increased over time from $11 \%$ in 2000 to $21 \%$ in 2012 . The simple average tariff rates for agricultural products also increased by $4 \%$ from 22.8 percent in 2000-04 to $26.8 \%$ in 2010 and the rate for non-agriculture has increased marginally (by about 1\%) during the same period (World Bank, 2012). Referring to this recent trend in protectionist trade policies, Pursell and Ahsan (2011) highlighted the serious potential damage to Sri Lanka's future economic growth, the resulting subversion of its preferential trade agreements and breach of WTO commitments. According to the current custom duty rates, the top rate remained as $25 \%$ for most of the goods with the exception of a few products. The new customs duty structure consists of four tariff bands (rates being 0\%,5\%,15\% and 30\%) and most of the agricultural products and a large number of final consumer goods ${ }^{2}$ are imposed with the top custom duty rates. The main purpose of restricting imports is the government's wish to protect local producers from foreign products.

\section{The Trade Policy Reversal Issue $e^{3}$}

Several recent studies on trade liberalisation policies in Sri Lanka have found that import policies have become more restrictive since 2001. The Agriculture sector was the most protected sector before 2000 and it has now become even more highly protected. Since 2000, the import protectiveness has increased gradually in the other sectors as well. Therefore, this new trend is seen as "the deliberate move back to import-substitution protectionism in both agriculture and manufacturing" (Pursell and Ahsan, 2011). The import tariff system in Sri Lanka has been transformed into a formula in combination with para-tariffs. Imports are subject to a number of taxes which make the domestic price of imported goods higher than when only ordinary custom duties, indirect taxes and excise duties are present.

Imports to Sri Lanka are subject to a plethora of levies and duties which are subject to frequent changes as each levy has its own applicable rate. Moreover, certain imported goods are provided with numerous preferential rates, concessions and exemptions. Information on these provisions is not apparent at the outset. The prominent feature of the Sri Lankan tariff schedule

\footnotetext{
${ }^{2}$ Highest rates are applied to tobacco products,

${ }^{3}$ Following the two papers of Athukorala (2012) and Pursell and Ahsan (2011).
} 
is its extreme complexity due to a large number of taxes on imports ${ }^{4}$. Currently eight types of taxes ${ }^{5}$ are imposed on imports. These eight types can be divided into three groups: 1) custom duties, 2) taxes with domestic equivalent, and 3) taxes with non-domestic equivalent. The second group includes four types of indirect taxes which have also been imposed on similar domestically produced goods. These are value added tax (VAT), Social Responsibility Levy (SRL), Nations Building Tax (NBT) and excise duties (Excise). The third group include three taxes which are imposed only on imported commodities. They are Ports and Airports Development Levy (PAL), Customs Surcharge (SUR) and Commodity Export Subsidy Scheme (Cess). The three groups are known as para-tariffs since there is no domestic equivalent in these taxes. In addition to these three taxes, there was the Regional Infrastructure Development Levy (RIDL) which was abolished in January 2011.

\section{Import Taxes with Domestic Equivalent}

Value added tax was introduced in 2002 since then amendments have been made almost every year. VAT is applied to goods and services supplied or imported to Sri Lanka with a standard rate of $12 \%$ maximum. The 2008 budget removed $\mathrm{VAT}^{6}$ from a number of domestically produced products. However, similar imported products have been subjected to VAT in 2009 according to the "Tariff Guide". Therefore, it has become another tax on imports. In addition to the VAT, there are three other import taxes which are domestic equivalent or approximately equivalent taxes. They have provisionally been judged to be roughly neutral in terms of protectiveness. These are the Social Responsibility Levy (SRL), the Nation Building Tax (NBT), and Excise duties. Finally, there is a "Special Commodity Levy" (SCL) on imports of a small number (22) of "essential" primary commodities. The SCL imposes specific duties which replace all the other import taxes (including Customs Duties and VAT) that would otherwise be imposed on imports of these products. Estimating the protectiveness for domestic producers of the SCL specific duties would require detailed information on the incidence of domestic taxes (if any) affecting these 22 products as well as the ad valorem equivalents of the specific duties, and has therefore not been attempted in this paper.

\footnotetext{
${ }^{4}$ There were 23 amendments and changes to import taxes in 2013 and 18 for such cases for 2014. See http://www.customs.gov.lk/cus_tariff.html.

${ }^{5}$ Provision of detail information on each type of tax has not been attempted in this paper.

${ }^{6}$ There were amendments every year. See http://www.ird.gov.lk/vat.html.
} 


\section{Para Tariffs}

The three taxes, PAL, SUR and Cess are considered as para-tariffs in Sri Lanka. They are referred to as para-tariffs because their protective impact is over and above the protection provided by customs duty (World Bank, 2004). They provide protection to domestic production similar to customs duties, are only applied to imports and have no domestic equivalent. Each of them has its own product coverage and this varies substantially between paratariffs. In 2013, the shares of total tariff lines subject to the PAL, SUR, and Cess were respectively $99.6 \%, 85.2 \%$, and $42.1 \%{ }^{7}$. However there are frequent changes in the product coverage of the para-tariffs, especially of the Cess (see Table 1). For example, the percentage of products subject to a Cess steadily increased between late 2004 and early $2010^{8}$, reducing from $38.6 \%$ in 2011 to 26.3 in 2012, 27.8 in 2013 and finally increasing to $35.6 \%$ in 2014. Cess rates were revised every year since $2010^{9}$ but preliminary analysis suggests that its product coverage and protectiveness were similar to 2010 revision.

Table 1: $\quad$ No. of tariffs lines covered by Cess

\begin{tabular}{ccccc}
\hline Cess rate & \multicolumn{4}{c}{ No. of tariffs lines covered by Cess } \\
\cline { 2 - 5 } & $\mathbf{2 0 1 1}$ & $\mathbf{2 0 1 2}$ & $\mathbf{2 0 1 3}$ & $\mathbf{2 0 1 4}^{* *}$ \\
\hline $5 \%$ & 218 & 135 & 124 & 142 \\
$10 \%$ & 206 & 186 & 188 & 152 \\
$15 \%$ & 103 & 34 & 110 & 291 \\
$20 \%$ & 89 & 59 & 59 & 104 \\
$25 \%$ & 96 & 35 & 40 & 82 \\
$30 \%$ & 595 & 335 & 357 & 420 \\
$35 \%$ & 148 & 94 & 124 & 148 \\
$45 \%$ & - & - & - & 9 \\
$50 \%$ & - & - & - & 18 \\
Total tariffs lines & 1455 & 878 & 1002 & 1366 \\
\hline
\end{tabular}

Source: Authors calculations based onSri Lanka Customs (2012, 2013a, 2013b) and 2014 budget proposal.

\footnotetext{
${ }^{7}$ The calculations are based in the Sri Lanka National Imports Tariff Guide-2013 and 13 various amendments to levies and charges on imports.

8 The 2004 and 2010 values are based on Pursell and Ahsan (2011).

${ }^{9}$ See Government of Sri Lanka (2012), Sri Lanka Customs (2012, 2013a, 2013b).
} 
Tariffs are often calculated as the ad valorem duties based on CIF (cost, insurance, and freight) price. In addition, imports are also subject to many different taxes. Import Cess is applicable on some products and can be ad-valorem, or specific, i.e. based on units of measure like weight or quantity. $\mathrm{Ad}=$ =valorem rates for Cess vary between $5 \%$ and $50 \%$ and are calculated on the CIF value. The Ports and Airport Levy (PAL) introduced in May 2002 is applicable on all imports at a standard rate of 5\%, or in some cases a reduced rate between $0 \%$ and $2.5 \%$, of the CIF value. The PAL was increased to $1.5 \%$ in February 2004, 2.5\% in January 2006, 3\% in January 2007, and 5\% in January 2009. The Customs Surcharge (SUR) was introduced at $40 \%$ (of the Customs duty) in February 2001, then changed to $20 \%$ (November, 2002), 10\% (January, 2004), 15\% (November, 2007) and finally abolished in June 2010. The RIDL was introduced in January 2007 at a nominal rate of $2.5 \%$ and then increased in 2008 to the alternative nominal rates of 5, 7.5 and 10\%. It was abolished in November 2010 (see Tables 2-6). 
Table 2: $\quad$ List of import taxes and their impact on tariff lines

\begin{tabular}{|c|c|c|c|c|c|c|c|}
\hline \multirow[t]{2}{*}{ Protective taxes } & \multirow[t]{2}{*}{ Abbreviation } & \multicolumn{2}{|c|}{$\%$ coverage of tariff line } & \multicolumn{2}{|c|}{2009} & \multicolumn{2}{|c|}{2012} \\
\hline & & 2009 & 2012 & $\begin{array}{l}\text { Max } \\
\text { rate }\end{array}$ & $\begin{array}{l}\text { Min } \\
\text { rate }\end{array}$ & $\begin{array}{l}\text { Max } \\
\text { rate }\end{array}$ & $\begin{array}{l}\text { Min } \\
\text { rate }\end{array}$ \\
\hline Custom duty & $\mathrm{CD}$ & 88.3 & 90.1 & 30 & & 30 & \\
\hline $\begin{array}{l}\text { Ports and airports } \\
\text { development levy }\end{array}$ & PAL & 99.4 & 99.5 & 5 & 2 & 5 & 2 \\
\hline Custom Surcharge & SUR & 86.1 & 87.8 & & & & \\
\hline $\begin{array}{l}\text { Commodity export } \\
\text { subsidy scheme }\end{array}$ & Cess & 39.9 & 40.1 & & & 50 & 4 \\
\hline $\begin{array}{l}\text { Regional } \\
\text { infrastructure }\end{array}$ & RIDL & 1.2 & $* *$ & & & & \\
\hline Value added tax & VAT & 91.2 & 92.1 & 20 & 12 & 20 & 12 \\
\hline $\begin{array}{l}\text { Social } \\
\text { Responsibility Levy }\end{array}$ & SRL & 100 & 100 & & & & \\
\hline Nation Building tax & NBT & 99.7 & 99.8 & 3 & 0 & 2 & 0 \\
\hline Excise tax & Excise & 4.1 & 4.3 & & & & \\
\hline $\begin{array}{l}\text { Special commodity } \\
\text { levy }\end{array}$ & SCL & 0.3 & & & & & \\
\hline
\end{tabular}


Table 3: $\quad$ Estimated un-weighted average protection from tariffs and para-tariffs

\begin{tabular}{|c|c|c|c|c|c|c|c|c|c|c|c|c|c|c|c|}
\hline & \multicolumn{3}{|c|}{2002} & \multicolumn{3}{|c|}{2004} & \multicolumn{3}{|c|}{2009} & \multicolumn{3}{|c|}{2011} & \multicolumn{3}{|c|}{2013} \\
\hline & $\mathrm{CD}$ & $\mathrm{PT}$ & TPR & $\mathrm{CD}$ & $\mathrm{PT}$ & TPR & CD & $\mathrm{PT}$ & TPR & $\mathrm{CD}$ & PT & TPR & CD & PT & TPR \\
\hline Agriculture & 21.1 & 5.2 & 26.3 & 24.6 & 3.5 & 28.1 & 24.56 & 25.0 & 49.6 & 25.4 & 21.4 & 46.8 & 25.12 & 24.99 & 49.55 \\
\hline Industry & 7.6 & 2.5 & 10.1 & 8.8 & 1.9 & 10.7 & 9.95 & 14.1 & 24.1 & 9.1 & 10.6 & 19.7 & 10.16 & 14.11 & 24.06 \\
\hline All tariffs lines & 9.6 & 2.9 & 12.5 & 11.3 & 2.1 & 13.4 & 12.12 & 15.7 & 27.39 & 11.5 & 12.2 & 23.7 & 12.85 & 15.73 & 27.85 \\
\hline
\end{tabular}

Source: Pursell and Ahsan (2011) p-26 and updated to 2013

$\mathrm{CD}=$ Custom duties, $\mathrm{PT}=$ Para-tariffs and TPR=Total protective rate

Table 4: $\quad$ Unweighted averages of MFN import taxes during 2009 to early June 2010 (\% of cif)

\begin{tabular}{|c|c|c|c|c|c|c|c|c|c|c|c|c|c|c|}
\hline \multirow[t]{2}{*}{ Sector } & \multirow{2}{*}{$\begin{array}{l}\text { No. of } \\
\text { HS- } \\
\text { lines }\end{array}$} & \multicolumn{4}{|c|}{ Non-protective import taxes } & \multirow{2}{*}{ Sub-total } & \multirow{2}{*}{$\begin{array}{l}\begin{array}{l}\text { Customs } \\
\text { duty }\end{array} \\
\text { (CD) }\end{array}$} & \multicolumn{4}{|c|}{ Protective para-tariffs } & \multirow{2}{*}{$\begin{array}{l}\text { Sub- } \\
\text { total }\end{array}$} & \multirow{2}{*}{$\begin{array}{l}\text { TPR } \\
\\
\text { (CD+ } \\
\text { tariffs) }\end{array}$} & \multirow{2}{*}{$\begin{array}{l}\text { Total- } \\
\begin{array}{l}\text { (all- } \\
\text { import- } \\
\text { taxes) }\end{array} \\
\end{array}$} \\
\hline & & VAT & SRL & NBT & Excise & & & PAL & SUR & Cess & $\begin{array}{l}\text { RID } \\
\text { L }\end{array}$ & & & \\
\hline Agriculture & 972 & 18.07 & 0.57 & 4.8 & 0.6 & 24.04 & 24.56 & 5 & 3.56 & 16.43 & 0 & 24.99 & 49.55 & 73.59 \\
\hline Industry & 5548 & 15.92 & 0.29 & 4.1 & 3.22 & 23.53 & 9.95 & 4.94 & 1.34 & 7.46 & 0.37 & 14.11 & 24.06 & 47.59 \\
\hline All-tariff-lines & 6520 & 16.24 & 0.33 & 4.2 & 2.83 & 23.6 & 12.12 & 4.95 & 1.67 & 8.79 & 0.32 & 15.73 & 27.85 & 51.45 \\
\hline
\end{tabular}


Table 5: $\quad$ Unweighted averages of MFN import taxes for 2013 (\% of cif)

\begin{tabular}{|c|c|c|c|c|c|c|c|c|c|c|c|c|c|}
\hline \multirow[t]{2}{*}{ Sector } & \multirow{2}{*}{$\begin{array}{l}\text { No. of } \\
\text { HS-lines }\end{array}$} & \multicolumn{4}{|c|}{ Non-protective import taxes } & \multirow{2}{*}{ Sub-total } & \multirow{2}{*}{$\begin{array}{l}\begin{array}{l}\text { Customs } \\
\text { duty }\end{array} \\
\text { (CD) }\end{array}$} & \multicolumn{3}{|c|}{ Protective para-tariffs } & \multirow{2}{*}{$\begin{array}{l}\text { Sub- } \\
\text { total }\end{array}$} & TPR & Total- \\
\hline & & VAT & SRL & NBT & Excise & & & PAL & SUR & Cess & & $\begin{array}{l}\text { (CD+ } \\
\text { tariffs) }\end{array}$ & $\begin{array}{l}\text { (all- } \\
\text { import- } \\
\text { taxes) }\end{array}$ \\
\hline Agriculture & 1126 & 18.63 & 0.61 & 2 & 0.68 & 21.92 & 25.12 & 5.5 & 4.21 & 19.1 & 28.81 & 53.93 & 75.85 \\
\hline Industry & 5590 & 14.23 & 0.31 & 1.85 & 4.21 & 20.6 & 10.16 & 5.21 & 1.36 & 7.85 & 14.42 & 24.58 & 45.18 \\
\hline All-tariff-lines & 6716 & 16.74 & 0.35 & 1.9 & 3.62 & 22.61 & 12.85 & 5.1 & 1.96 & 9.16 & 16.22 & 29.07 & 51.68 \\
\hline Table 6: & Unweig & average & of $\mathrm{M}$ & $\mathrm{Nim}$ & ort taxe & proposed & for $2014^{11}$ & $\%$ of $\mathrm{ci}$ & & & & & \\
\hline \multirow[t]{2}{*}{ Sector } & No. of & \multicolumn{4}{|c|}{ Non-protective import taxes } & & $\begin{array}{l}\text { Customs } \\
\text { duty }\end{array}$ & \multicolumn{3}{|c|}{ Protective para-tariffs } & & TPR & Total- \\
\hline & HS-lines & VAT & SRL & NBT & Excise & Sub-total & (CD) & PAL & SUR & Cess & $\begin{array}{l}\text { Sub- } \\
\text { total }\end{array}$ & $\begin{array}{l}(\mathrm{CD}+ \\
\text { tariffs })\end{array}$ & $\begin{array}{l}\text { (all- } \\
\text { import- } \\
\text { taxes) } \\
\end{array}$ \\
\hline Agriculture & 1216 & 19.74 & 0.64 & 2.13 & 0.68 & 23.19 & 25.86 & 5.5 & 4.21 & 19.23 & 28.94 & 54.8 & 77.99 \\
\hline Industry & 5628 & 16.92 & 0.31 & 2.1 & 4.21 & 23.54 & 9.95 & 5.21 & 1.36 & 8.41 & 14.98 & 24.93 & 48.47 \\
\hline All-tariff-lines & 6844 & 18.23 & 0.37 & 2.01 & 3.62 & 24.23 & 13.12 & 5.1 & 1.96 & 9.21 & 16.27 & 29.39 & 53.62 \\
\hline
\end{tabular}

\footnotetext{
${ }^{11}$ Based on (Sri Lanka Customs, 2013)
} 


\section{A Multi-household CGE Model for the Sri Lankan Economy}

Single country CGE models have widely been used to evaluate the effects of trade policy related issues in both developed and developing countries for a period extending the last three decades (See Bandara, 1991; Decaluwé et al., 1999). In this study we develop a CGE model for Sri Lanka to examine the economy-wide effects of trade policy reversal. Since the CGE modelling technique is well-established in the empirical economic literature we do not intend to provide the technical details of the modelling technique or the procedure of deriving the equation system of the model in this paper. Rather we will provide a brief overview of the model.

The theoretical structure of the Sri Lankan CGE model very closely follows the well-known Australian ORANI model which is a comparative static type CGE model (Dixon et al., 1982). A number of CGE models have been developed for Sri Lanka following the ORANI model (For example, Bandara, 1989; Naranpanawa, 2005; Naranpanawa et al., 2011). However, for two reasons, a new model is developed in this study. Firstly, none of previously developed CGE models for Sri Lanka are publicly available for current policy analysis. Secondly, those models cannot be directly used for the purpose of this study without making necessary changes to the number of representative households and occupational categories in order to examine the effects of trade policy reversal on income distribution and different employment categories. Finally, data used in previous models are outdated. In order to incorporate multiple household categories, we decided to follow the tradition of the South African CGE model which is an extension of the ORANI model and based on a social accounting matrix, SAM (Horridge et al., 1995).

Similar to many other CGE models in the ORANI family the CGE model developed in this study is a comparative static CGE model and consists of a number of common equation blocks describing:

- Producers' demands for produced inputs and primary factors including different occupational categories of labour;

- Producers' supplies of commodities;

- Demands for inputs to capital formation;

- Household demands by different household groups;

- Export demands;

- Government demands;

- The relationship of basic values to production costs and to purchasers' prices;

- Market clearing conditions for commodities and primary factors;

- Macroeconomic variables and price indices; and 
- Other miscellaneous equations.

The above equations are derived using well-known neo-classical assumptions in microeconomics based on the behaviour of different agents in the economy. It is assumed that consumers maximise utility, subject to their budget constraints, and producers choose inputs to minimise production costs and maximise profits. It is also assumed that both product and factor markets are perfectly competitive. Demand equations for inputs in production are derived by using nested production functions with constant elasticity of substitution (CES) and Leontief functional forms. In deriving demand functions for different household groups, the nested utility functions are used. While the outer nest of these combines composite commodities using a CobbDouglas functional form, the inner nest forms composite commodities from imported and domestic variants using a CES functional form for each composite. The allocation of household expenditure between commodity composites is derived from the Klein-Rubin utility function.

The new Sri Lankan CGE model has three representative households and nine occupational categories. The CGE model contains 57 industries, which produce 57 commodities. In order to implement the model, a SAM was developed as the main database using a base year of 2007. The core of the 2007 SAM is an input-output table which is derived from version 8 of the GTAP database (Aguiar et al., 2012). In order to extend the 2007 I-O table to a SAM, national accounts for the year 2007 and the Household Income Expenditure Survey (HIES) HIES 2009/10, which was based on a nationally representative sample of 19,958 households in Sri Lanka, were used. The widely used general equilibrium modelling (GEMPACK) software package (Harrison and Pearson, 1996; Horridge et al., 2000) was then applied to solve our model similar to other ORANI type CGE models.

\section{The Effects of Trade Policy Reversal: Simulation Results}

The illustrative economy-wide effects of trade policy reversal can be examined by using the above described CGE model. As explained previously, para-tariffs have increased compared to tariffs on imports in Sri Lanka in the recent past. Therefore, the ideal situation is to incorporate the para-tariff increase in the simulation. However, the present study does not undertake this due to the complexity of para-tariff structure. Alternatively, tariffs are used in the simulation while assuming the effects of both types of protection measures are approximately similar. In order to do so, two policy simulations are carried out in relation to the short-run and long-run. This is performed by increasing the existing tariffs $50 \%$ for all sectors to evaluate the illustrative directions and magnitudes of the effects of trade liberalisation on macro 
variables, industry level variables and household impact. In CGE modelling literature, the classification of variables into exogenous and endogenous variables is known as the "closure" or "economic environment". A brief description of the closure used in this study is given below.

\section{Short Run Closure}

The short run closure defines the supply side and the demand side of the economy to carry out the simulation more appropriately to the trade policy change. On the supply side of the economy, capital stocks at the aggregate level and industry level, the real wages, technology, and other primary factors, such as land, are fixed in the short run simulation. The capital stock is fixed in each industry assuming industry-level output can be changed only through changes in labour input. It is assumed in the short run closure that the time period concerned is not long enough to change the capital stock through investments. The rate of return of the capital is determined according to the fixed capital stock. It assumes that labour is mobile between industries, and that supply of each skill type is elastic. Given the fixed real wage assumption, it is also assumed that the model determines the aggregate employment level for the whole economy, for each sector, and for each occupational category. While balance of payment is allowed to change in the short run, the nominal exchange rate which is used as the common numeraire is fixed. The demand side of the short run closure can now be considered. The aggregate demand in the economy is determined by real private consumption expenditure, exports, and imports according to the short-run closure. In other words these variables are exogenous and the real investment and real government expenditure are assumed to be fixed in the short-run closure.

\section{Long Run Closure}

The long run closure defines exogenous and endogenous variables from the supply side and the demand side of the economy. Exogenous variables constraining real GDP from the supply side are gross sectoral rates of return, industry-specific endowments of land, aggregate employment, technology and other primary factors such as land. In the long-run, aggregate employment is fixed and real wages are allowed to change. While rate of return on capital is assumed to be fixed, the capital stock is allowed to change to maintain the given rate of return. In the long run closure, most of the aggregate demand components are endogenously determined. These components include real private consumption expenditure, aggregate investment, exports and imports. While the balance of trade is set as exogenous, exchange rate is fixed and acts as the numeraire similar to short run. 


\section{Empirical Results: Macroeconomic Effects}

In this section we present the macroeconomic effects of our illustrative simulation, i.e., 50\% increase in tariffs across the board. Similar to any other presentation of results carried out by a CGE exercise following the ORANI tradition, the results related to both macro and micro variables presented in this paper are in percentage change form except for a small number of variables which are in change form. Following this tradition, the effects of tariff increases by $50 \%$ on macroeconomic variables in percentage changes are summarised in Table 7. According to the results shown in Table 7, real GDP, aggregate employment, exports, and imports are projected to decline as a result of an increase in tariffs both in the short run and in the long run. GDP is also expected to decline at a higher rate of $1.45 \%$ (from the base case) in the long run than in the short run (i.e. $-0.845 \%$ ). The real investment and changes in the capital stock are predicted to be negative in the long run. As expected, the consumer price index is projected to rise both in the short run and long run as a result of an increase in tariffs which will result in a decline in household real consumption. The economy is expected to experience higher reduction in real consumption in the short run than that of in the long-run and exports are also expected to suffer from an increase in tariffs across the board by 50\%. The increase in tariffs has generated negative values for both exports and imports.

Table 7: $\quad$ Projections of percentage change in macro variables under different policy simulations in the short run and long run.

\begin{tabular}{lcc}
\hline Description & Short Run & Long Run \\
\hline Real gross domestic product & -.845 & -1.447 \\
Aggregate Employment & -1.529 & Exogenous \\
Average real wages & Exogenous & 1.632 \\
Consumer Price Index & 1.906 & 1.632 \\
Real Consumption Change & -1.34 & -0.531 \\
Export change & -4.02 & -6.965 \\
Aggregate real investment expenditure & Exogenous & -2.662 \\
Import change & -3.05 & -3.947 \\
\hline
\end{tabular}


The effects on GDP shown in Table 7 can be explained by using simple GDP identity in an open economy. GDP can be considered as the quantity index of the flow of goods and services produced in the economy. Percentage in the real GDP can be defined as the weighted average of percentage changes in four aggregate expenditure components [private consumption (C ); investment (I); government expenditure (G) and net exports $(\mathrm{X}-\mathrm{M})]$ given below:

$G D P=C c+I i+G g+X x-M m$

where $C, I, G, X$, and $M$ are the $G D P$ shares of aggregate real private consumption, aggregate real investment expenditure, government expenditure, and exports and imports respectively. These shares can be calculated from the base year database of the model and they are 0.704, 0.259, 0.160, 0.287, and 0.410 respectively. The predicted values by the CGE model for the percentage change of each component represented by $c, i, g, x$ and $m$ are given in Table 7 . It is assumed in the short run that the capital stock, real investment and the government expenditure are fixed. Therefore, change in aggregate expenditure is caused by reduction in real aggregate consumption, exports and imports. By setting $i=g=0$ in Equation 1, the short run change in real GDP can be explained as:

$\mathrm{GDP}=(0.704 *-1.339)+(0.287 *-4.02001)-(0.41 *-3.05)=-.845$

In the long run, the capital stock is allowed to change while the aggregate employment and the government expenditure are fixed. Therefore, change in aggregate expenditure is caused by reduction in real aggregate consumption, investments, exports and imports. By setting $g=0$ in the long run, the change in real GDP can be explained as follows using Equation 1.

$\mathrm{GDP}=(0.704 *-0.532)+(0.259 *-2.662)+(0.287 *-6.965)-(0.410 *-3.947)=-1.446$

\section{The Effects on Households}

As explained in Section 3, the model developed in this study contains a number of household categories. Therefore, the effects of an increase in tariffs on different household categories can be examined briefly in this section. Households act as both consumers and factor owners and the model allows us to analyse the impact of households. There are several channels through which changes in tariffs affect household welfare. The change in the prices of goods consumed and produced by households is only one of the channels through which higher trade restrictiveness affects the households' 
welfare. The other important channel is the labour market channel. As households receive a substantial part of their income by selling their labour, the impact of tariff hikes on labour earnings can be stronger. It is well known that if an increase in tariffs passes through on domestic prices, the factor market will be in disequilibrium thereby resulting in factor income adjustments.

Table 8: $\quad$ Household effect of tariff increase

\begin{tabular}{lcccccc}
\hline & \multicolumn{2}{c}{ Urban } & \multicolumn{2}{c}{ Rural } & \multicolumn{2}{c}{ Estate } \\
\cline { 2 - 7 } & SR & LR & SR & LR & SR & LR \\
\hline $\begin{array}{l}\text { Consumer price } \\
\text { index }\end{array}$ & 1.86 & 1.60 & 1.91 & 1.63 & 2.10 & 1.83 \\
$\begin{array}{l}\text { Real wages } \\
\text { Real Household }\end{array}$ & $*$ & -1.03 & $*$ & -1.05 & $*$ & -0.87 \\
\begin{tabular}{l} 
consumption \\
\hline
\end{tabular} & -1.31 & -0.30 & -1.35 & -0.63 & -1.45 & -0.77 \\
\hline
\end{tabular}

*Exogenous

Table 9: $\quad$ Employment level by occupational category

\begin{tabular}{lcc}
\hline Occupational category & \multicolumn{2}{c}{ Employment } \\
\cline { 2 - 3 } & SR & LR \\
\hline Managers & -1.6 & 0.1 \\
Professionals & -0.8 & -0.1 \\
Technicians & -1.8 & 0.1 \\
Clerks & -1.5 & 0.2 \\
Services & -1.4 & 0.6 \\
Skilled agriculture & -0.5 & 0.7 \\
Craft workers & -2.0 & -1.1 \\
Machine operators & -2.7 & 0.2 \\
Elementary occupations & -1.2 & 0.2 \\
\hline
\end{tabular}

While the consumer price level in all sectors is expected to rise over one percent as a result of an increase in tariff, the estate sector is expected to suffer heavily from the price rise (see Table 8: Household effect). Urban areas are found to be generally less affected than the rural sector due to the households' lower reliance on agricultural sales and higher reliance on skilled 
wages. Moreover, the exposure of rural households to tariff changes tends to be smaller. The estate sector, on the other hand, is projected to be the worst affected by the tariff increase. One reason for this is that the types of goods that the estate sector consumes are directly affected by tariff increases through consumer price increases. The other reason is the contraction of the export sector as their livelihoods is mostly dependent on this sector's performances. Table 9 presents the effects of a 50\% increase in all tariffs on different occupational categories of labour both in the long run and the short run. In the short run, demand for labour in each occupational category has declined. In contrast the demand for labour in most of the occupational categories has increased with the exception of professional and craft workers in the long run. Real household consumption has declined in all three household sectors in both short-run and long-run in different magnitudes. However, negative effect on household consumption in the short-run is higher than their long-run values. These household level results indicate the overall negative effect of tariff increase on household welfare. All household groups experience a significant welfare loss due to reduction in real household consumption and increase in consumer prices.

\section{The Effects on Different Sectors}

Increase in trade restrictions are expected to influence different industries in agriculture, manufacturing and services sectors in terms of output and employment. The output of most of agricultural subsectors showed a decline in the short run compared to the long run (see Appendix Table 1).As a result, change in employment in this sector followed a similar pattern. In contrast to this, the opposite has happened in the long run in that most of the agricultural sub-sectors have increased the demand for labor while expanding their economic activities. For example, $70 \%$ of subsectors were contracted in the short run simulation within the industrial sector. Most of the subsectors in the manufacturing and services sectors were negatively affected in the short run as well as in the long run. Over $80 \%$ of manufacturing sectors including textiles, wearing apparels, wood products, chemical products, and motor vehicle and transport equipment experienced a significant reduction in output and demand for labour. The main reason for the contraction of these subsectors was that they are heavily dependent on imported raw materials and intermediate goods which gradually become more costly due to tariff hikes. Since majority of the Sri Lankan exports are manufacturing, any policy which affects negatively on the manufacturing sectors, will also affect the exports in the same way. 


\section{Concluding Remarks}

It is a well-established in the literature that open economic policies contribute positively to economic growth, employment generation and aggregate poverty reduction in comparison with closed economic policies. In contrast to the established empirical evidence, policy makers in some countries have made an effort to achieve better economic outcomes by reversing open economic policies in recent years. This study attempted to demonstrate the possible negative outcomes resulting from are vival of protectionism by using an illustrative policy simulation. It used Sri Lanka as a case study and developed a CGE model for the Sri Lankan economy in order to simulate the effects of a hypothetical tariff rise across the board by $50 \%$ following the recent trend in rising para-tariffs.

The results of the illustrative tariff simulation carried out with a detailed CGE model developed for the Sri Lankan economy suggest that developing countries will not benefit from returning to protectionism in the form of increasing tariffs or para-tariffs. The results of this study indicate that an increase in tariffs will have a negative impact on exports, employment and GDP as predicted by the traditional theory of protection. Our results further demonstrate that manufacturing sectors are affected by the rising cost of intermediate inputs as a result of an increase in tariffs. The export-oriented labour intensive industries also become less competitive forcing them to reduce labour force which in turn has a negative impact on poverty.

Projections of this study show restrictive trade policies may lead to a decline in employment in the manufacturing and services sectors as a result of a decline in the demand for labour by these sectors. The possible effect in such a situation is to create unemployment. On one hand, a reduction in labour income for workers in all sectors and an increase in consumer prices across all household groups, with workers losing jobs as a result of lack of activities, will push the households into a welfare loss. The analysis based on the negative real consumption in both policy scenarios indicates a possible welfare loss due to tariff increase on each household group. This provides useful information for a detailed assessment of the impact on poverty of trade policy reversal issues in the recent Sri Lankan policy agenda.

Before ending this section it is important to note that there are limitations of this study and the results should be interpreted with caution. This is a preliminary analysis based on a comparative-static CGE model developed for the Sri Lankan economy. The model does not contain dynamic elements. As noted previously, the simulation carried out in this study is also an illustrative one with a hypothetical tariff increase of $50 \%$ rather than an actual increase in para-tariff levels as has been used in the recent past. 
Therefore, the magnitudes of changes in different variables should be treated as indicative. In creating future research agendas it is also evident that consideration needs to be given to eliminating some of the above limitations.

\section{Reference}

Aguiar, A., R. McDougall and B. Narayanan (2012). Global Trade, Assistance, and Production: The GTAP 8 Data Base.

Athukorala, P. and S.K. Jayasuriya (1994). Macroeconomic Policies, Crises, and Growth in Sri Lanka, 1969-90: World Bank Washington, DC.

Athukorala, P. (2012). Sri Lanka's Trade Policy: Reverting to Dirigisme? The World Economy, 35(12):1662-1686.

Athukorala, P. and S. Rajapatirana (2000). Liberalization and Industrial Transformation: Sri Lanka in International Perspective. Oxford and Delhi: Oxford University Press.

Bandara, J. (1989). A Multi Sectoral General Equilibrium Model of the Sri Lankan Economy with an Application to the Analysis of rhe Effects of External Shocks. Unpublised PhD Thesis La Trobe Melbourne .

Bandara, J.S. (1991). Computable General Equilibrium Models for development Policy Analysis in LDCs. Journal of Economic Surveys, 5(1):3-69.

Bandara, J.S. (2011). Trade and Poverty: Theory, Evidence and Policy Issues, Chapter 2 in Trade Liberalisation and Poverty in South Asia (Vol. 105): Routledge.

Bandara, J.S. and A. Naranpanawa (2014). Garment Industry in Sri Lanka and the Removal of GSP Plus by EU. The World Economy, doi: $10.1111 /$ twec. 12182

Bussière, M., E. Pérez-Barreiro, R. Straub D. and Taglioni (2011). Protectionist Responses to the Crisis: Global Trends and Implications. The World Economy, 34(5):826-852.

Central Bank (2012). Annula Report. Central Bank, Sri Lanka. 
Cuthbertson, A.G., and P. Athukorala (1990). Liberalizing Foreign Trade: The Experience of Sri Lanka Liberalizing foreign trade: The Experience of Indonesia, Pakistan and Sri Lanka: Oxford: Basil Blackwell.

Decaluwé, B., A. Patry, L. Savard and E. Thorbecke (1999). Poverty Analysis within a General Equilibrium Framework. Documento de Trabajo CREFA, 9906.

Department of Census and Statistics (2004). Poverty Statistics and Indicators for Sri Lanka.

Department of Census and Statistics (2006). Poverty Statistics and Indicators for Sri Lanka.

Department of Census and Statistics (2010). Poverty Statistics and Indicators for Sri Lanka.

Dixon, P.B., B.R. Parmenter, J. Sutton and D.P. Vincent (1982). ORANI: A Multisectoral Model of the Australian Economy: North-Holland Amsterdam.

Dunham, D. (1997). Stabilization and Adjustment: A Second Look at the Sri Lankan Experience, 1977 - 93. The Developing Economies, 35(2): 166-184.

Dunham, D.M. and S. Kelegama (1994). Economic Liberalization and Structural Reforms: The Experience of Sri Lanka, 1977-93. ISS Working Paper Series/General Series, 163:1-37.

Gamberoni, E. and R. Newfarmer (2009). Trade Protection: Incipient but Worrisome Trends. The Collapse of Global Trade, Murky Protectionism, and the Crisis: Recommendations for the G20, 49.

Government of Sri Lanka. (2012). Government Notifications: Sri Lanka Export Development Act. Retrived from <www.customs.gov.lk/tariff/Import Cess Gazette 2012 (English)Amended 24.pdf>

Harrison, W.J. and K.R. Pearson (1996). Computing Solutions for Large General Equilibrium Models using GEMPACK. Computational Economics, 9(2):83-127. 
Horridge, M., B. Parmenter, M. Cameron, R. Joubert, A. Suleman and D. de Jongh (1995). The Macroeconomic, Industrial, Distributional and Regional Effects of Government Spending Programs in South Africa: Monash University, Centre of Policy Studies/IMPACT Centre.

Horridge, M., B.R. Parmenter and K.R. Pearson (2000). ORANI-G: A General Equilibrium Model of the Australian Economy: Centre of Policy Studies.

Jayawardena, L., A. Maasland and P. Radhakrishnan (1987). Stabilization and Adjustment Policies and Programmes: Sri Lanka. World Institute for Development Economics Research of the UN University.

Kaminski, B. and F. Ng (2013). Increase in Protectionism And Its Impact On Sri Lanka's Performance In Global Markets. Development Research Group, The World Bank, Washington D.C.

Kelegama, S. and D. Dunham (1994). Economic Liberalisation and Structural Reforms: The Expereince of Sri Lanka, 1977-1993. Paper presented at the Second international Conference on Development and Future Studies.

Kelegama, S. and F. Foley (1999). Impediments to Promoting Backward Linkages from the Garment Industry in Sri Lanka. World Development, 27(8):1445-1460.

Naranpanawa, A. (2005). Trade Liberalisation and Poverty in a Computable General Equilibrium (CGE) Model: The Sri Lankan Case, Unpublished $\mathrm{PhD}$ Thesis. Griffith Business School, Griffith University.

Naranpanawa, A., J.S. Bandara and S. Selvanathan (2011). Trade and Poverty Nexus: A Case Study of Sri Lanka. Journal of Policy Modeling, 33(2):328-346.

Pursell, G. and F.M.Z. Ahsan (2011). Sri Lanka's Trade Policies: Back to Protectionism. ASARC Working Papers.

Singh, T. (2010). Does International Trade Cause Economic Growth?: A Survey. The World Economy, 33(11):1517-1564.

Snodgrass, D.R. (1966). An Export Economy in Transistion. New Haven Growth Centre, Yale University 
Sri Lanka Customs (2013). Revenue Protection Order 03/2013. Retrived from <http://www.customs.gov.lk/tariff/2014cid.pdf>.

Wignaraja, G. (1998). Trade Liberalization in Sri Lanka: Exports, Technology, and Industrial Policy. London: Macmillan Press.

Winters, A., N. McCulloch and A. McKay (2004). Trade Liberalization and Poverty: The Evidence So Far. Journal of Economic Literature, 42(1):72-115.

World Bank. (2004). Trade Policies in South Asia: An Overview.

World Bank. (2012). World Development Indicators 2012: World Bank, Washington D.C. 


\section{Appendix}

Table 1: $\quad$ Projections of percentage change in industry activity level and employment effects

\begin{tabular}{lcccc}
\hline Sector & $\begin{array}{c}\text { \% change in industry } \\
\text { employment level }\end{array}$ & \multicolumn{2}{c}{$\begin{array}{c}\text { \% change in industry } \\
\text { activity level }\end{array}$} \\
\cline { 2 - 5 } & Short Run & Long Run & Short Run & Long Run \\
\hline Agriculture & & & & \\
Paddy rice & -0.31 & 1.07 & -0.12 & 0.49 \\
Cereal grain & -3.44 & -1.01 & -1.33 & -0.67 \\
Vegetable, fruit, nut & 0.76 & 1.74 & 0.29 & 0.86 \\
Oil seeds & -1.00 & 0.60 & -0.38 & 0.23 \\
Sugar cane, sugar beet & -0.54 & 1.59 & -0.21 & 0.78 \\
Plant-based fibres & -17.94 & -13.70 & -7.85 & -8.34 \\
Crops & -0.57 & 0.38 & -0.22 & 0.10 \\
Animal products & -1.09 & 0.51 & -0.42 & 0.18 \\
Wool, silk-worm cocoons & 0.00 & 0.00 & 0.00 & -9.69 \\
Forestry & -0.78 & 0.49 & -0.32 & 0.21 \\
Fishing & -0.54 & 0.32 & -0.10 & -0.02 \\
Industry & & & & \\
Coal & 0.00 & 0.00 & 0.00 & -0.51 \\
oil & 0.00 & 0.00 & 0.00 & -0.07 \\
Gas & 0.00 & 0.00 & 0.00 & -0.74 \\
Mineral & -0.80 & -1.24 & -0.26 & -1.42 \\
Manufacturing & & & & \\
Meat products & -4.73 & 3.65 & 0.27 & 1.26 \\
vegetable oils and fats & -1.94 & 0.57 & -0.35 & -1.59 \\
Dairy products & 4.36 & 7.01 & 0.53 & 4.63 \\
Sugar & 0.00 & 0.00 & 0.00 & 2.40 \\
Food products & -4.72 & 0.64 & -0.63 & -1.64 \\
Beverages and tobacco & 1.78 & 3.30 & 0.13 & 0.83 \\
products & -4.38 & -2.61 & -1.21 & -4.72 \\
Textiles & -4.57 & -1.91 & -1.24 & -4.04 \\
Wearing apparel & -4.64 & 0.78 & -1.21 & -1.41 \\
Leather products & -4.25 & -0.10 & -2.12 & -1.59 \\
Paper products, publishing & & & & \\
\hline
\end{tabular}


60

Table 1 contd..: Projections of percentage change in industry activity level and employment effects

\begin{tabular}{lcccc}
\hline Sector & \multicolumn{2}{c}{$\begin{array}{c}\text { \% change in industry } \\
\text { employment level }\end{array}$} & \multicolumn{2}{c}{$\begin{array}{c}\text { change in industry } \\
\text { activity level }\end{array}$} \\
\cline { 2 - 5 } & Short Run & Long Run & Short Run & Long Run \\
\hline Petroleum, coal products & 20.20 & 4.24 & 1.65 & 1.48 \\
Chemical, rubber, plastic & -4.54 & -1.03 & -0.85 & -3.41 \\
products & & & & \\
Mineral products & -3.44 & 0.23 & -0.89 & -1.95 \\
Ferrous metals & 0.00 & 0.00 & 0.00 & -4.81 \\
Metal & -14.74 & -9.49 & -4.27 & -11.50 \\
Metal products & -3.78 & -1.43 & -1.78 & -2.99 \\
Motor vehicles and parts & -4.85 & -0.02 & -1.85 & -1.85 \\
Transport equipment & -13.61 & -9.20 & -7.33 & -10.52 \\
Electronic equipment & -8.23 & -2.22 & -2.06 & -4.41 \\
Machinery and equipment & -10.49 & -7.25 & -4.51 & -8.88 \\
Manufactures & -13.07 & -10.68 & -5.71 & -12.27 \\
Electricity gas water & & & & \\
Electricity & -7.87 & 0.25 & -1.24 & -2.24 \\
Gas manufacture, & -2.34 & 1.39 & -0.44 & -1.02 \\
distribution & & & & \\
Water & -5.67 & 1.54 & -2.17 & -0.30 \\
Construction & -0.30 & -0.97 & -0.19 & -2.14 \\
Services & & & & \\
Trade & -1.47 & 1.43 & -0.49 & -1.21 \\
Transport & -2.74 & 1.06 & -1.01 & -1.43 \\
Water transport & -8.18 & -2.36 & -2.53 & -5.05 \\
Air transport & -2.71 & 1.16 & -0.89 & -1.48 \\
Communication & -8.08 & 2.35 & -0.01 & -0.62 \\
Financial services & -0.60 & -0.15 & -0.45 & -0.88 \\
Insurance & -4.01 & 1.68 & -3.20 & 1.07 \\
Business services & -1.84 & -0.56 & -1.36 & -1.32 \\
Recreational and other & -1.72 & 0.30 & -1.37 & -0.30 \\
services & -0.32 & -0.16 & -0.32 & -0.16 \\
Public administration and & & & & \\
defence, education, health & 0.00 & 0.00 & 0.00 & 0.00 \\
Dwellings & & & & \\
\hline
\end{tabular}

